\title{
Forty years of my adventures with Cladocera remains: retrospection on my scientific work
}

\author{
Krystyna Szeroczyńska $\mathbb{D}$
}

Received: 8 January 2019/Accepted: 22 January 2019/Published online: 1 March 2019

(C) The Author(s) 2019

Keywords Subfossil Cladocera .

Paleolimnology · IPA Lifetime Achievement

Award

\section{Introduction}

First, I would like to express my gratitude for the Lifetime Achievement Award that was bestowed upon me by the International Paleolimnology Association (IPA). I thank both the Commission and the people who nominated me for this distinguished award. This honour was the result not only of my own scientific work, but of collaborations with many scientists with whom I have had the pleasure of working for more than 40 years. The award is very important to me, as it gives special meaning to my professional and life choices. It is gratifying to realise that through my scientific work and research on Cladocera remains, I contributed to the development and importance of paleolimnology. In this epoch of extreme changes in the natural environment, paleolimnological studies are

The author was the recipient of a "Lifetime Achievement Award" presented by the International Paleolimnology Association in Stockholm, Sweden, on 20 June 2018.

K. Szeroczyńska ( $\bowtie)$

Institute of Geological Sciences, Polish Academy of

Sciences, Twarda 51/55, PL00818 Warsaw, Poland

e-mail: kszerocz@twarda.pan.pl becoming increasingly important (Smol 2012). Such studies enable us to infer changes that occurred in the past, to better understand contemporary changes, and to anticipate changes that will occur in the future. In paleolimnological studies, many types of biological analyses contribute to environmental reconstructions, and subfossil Cladocera analyses are among the most important (Korhola and Rautio 2001). Cladocera remains played a major role in my scientific career, and as I reminisce about my professional journey, I would like to emphasize the importance of research on this faunal group.

I am grateful to the Directors and Heads of the Institute of Geological Sciences of the Polish Academy of Sciences in Warsaw, who were my superiors during my more than 40-year career. They recognised the importance of paleolimnological studies and enabled me to pursue the analysis of Cladocera remains at the Institute as part of the study of geological profiles, under the broad umbrella of Quaternary research.

\section{The beginning}

It is likely that few people are aware that my first professional occupation was as a pharmacist at a hospital pharmacy, a job that gave me a lot of joy and satisfaction. Nevertheless, after I graduated from biological studies and defended my Master's thesis 
in 1975 under the supervision of hydrobiologist Józef Mikulski (Nicolaus Copernicus University in Toruń), my interests changed completely. My MS thesis, which focused on the analysis of lakes and zooplankton species composition, gave me great satisfaction and made aquatic invertebrates my life passion. I was very lucky to have met people of science, geologists who enabled me to pursue my passion for hydrobiology and combine it with sediment studies. My first contact with paleolimnology was during the 2nd International Symposium on Paleolimnology (14-20 September 1976, Mikołajki, Poland), when I was hired by Barbara Marciniak (the main host) to assist with organisation. The meeting of more than 130 paleolimnologists in Mikołajki included many of international renown, made a great impression on me and affected my future professional life. It was then that I decided to use my knowledge of modern Cladocera to reconstruct changes that had occurred in the natural environment in the past, and to incorporate the analysis of subfossil Cladocera into the methods for study of Quaternary sediments.

In 1976, I was employed as a laboratory assistant at ING PAN (Institute of Geological Sciences, Polish Academy of Sciences), where, in addition to my laboratory duties as a technical assistant, I was able to carry out my own research on Cladocera remains. I have worked at the Institute to this day, moving through the ranks of my scientific career-from a technical assistant to a full professor. The early years were difficult, because in the 1970s, analysis of subfossil Cladocera in Poland was little known and done only occasionally (Czeczuga and Kosacka 1977; Mikulski 1978). Furthermore, no taxonomic identification keys were available at that time, which made it very difficult to identify Cladoceran or Cladocera remains. Thanks to several scholarships (i.e. DAAD, Science Foundation in Austria, and the Polish Academy of Sciences, in Poland), I was able to participate in research internships abroad and make use of library and archival resources. I also received assistance from specialists including Wolfgang Hofmann (Max Planck Institute for Limnology, Plön, Germany) and Nikolai N. Smirnov (Institute of Ecology and Evolution RAS, Moscow, Russia), to whom I am very grateful. I am also very grateful to J. Mikulski, who not only instilled in me a passion for zooplankton while I was preparing my MS thesis, but also continuously encouraged me and provided invaluable professional help during my independent academic work. My most sincere gratitude goes to the late Professor David G. Frey (Indiana University, Bloomington, USA), who, whenever he visited Poland, always found time for discussions, and provided me with professional and methodological advice, as well as assistance with identification of Cladocera remains. David Frey was a great man, who inspired others with his knowledge and passion for Cladocera analysis. He had a tremendous influence on my scientific work, reassured me of the value of Cladocera remain analysis, verified my taxonomic identifications of remains, and proofread my first papers. In our conversations about Cladocera remains, funny situations often occurred, mainly related to nomenclature, which resulted from his use of the "American version" of Latin species names and my use of the "Polish version." I recall those moments with great sentiment and hope that I have inspired my students with the same passion David Frey used to inspire me.

\section{Brief outline of the research}

In Poland, research in the field of paleolimnology advanced substantially from 1980 to 1990 , owing to a group of scientists who represented various fields of science, from palynology to archaeology. As a member of such a group, and one who cooperated with scientists from multiple disciplines, I benefited from their broad knowledge and expertise, and became aware of the importance of interdisciplinary collaboration and the value of results provided by studies in other fields, e.g. archaeological investigations, for environmental reconstruction. In the 1980s, I focused mainly on Cladocera from paleolakes-Woryty (Pawlikowski et al. 1982) and Niechorze (KopczyńskaLamparska et al. 1983), on which I wrote my doctoral thesis (Szeroczyńska 1985). A breakthrough in my scientific work came with the research carried out at sites in Błędowo and Gościąż (Bińka et al. 1988, 1991; Goslar et al. 1991; Szeroczyńska 1991, 1998d). Lake Gościąż became a reference site for Central Europe, and results of research carried out on its annually laminated sediments were presented in a number of papers (e.g. Goslar et al. 1993, 1997, 1999; RalskaJasiewiczowa et al. 1997), as well as a monograph (Ralska-Jasiewiczowa et al. 1998). Multiple analyses 
of the laminated sediments from this lake enabled high-resolution (annual) inference of ecological and climate changes in Central Europe during the Late Glacial and Holocene. I presented the laminated sediments of Lake Gościąż and the results of the analysis of Cladocera remains deposited over the last 13,000 years at multiple scientific symposia. Results from a detailed analysis of Cladocera in the Late Glacial and Holocene (6-year resolution in the Late Glacial and 50-year resolution in the Holocene) became a "window" for me into the "world of science" (Ralska-Jasiewiczowa et al. 1997; Szeroczynska 1998c, d). For many years, I participated in international symposia on Cladocera and paleolimnology. I expanded my knowledge of modern and subfossil Cladocera, and presented results of my analyses of Cladocera remains from heterogeneous lake sites (Szeroczyńska 1998b, 1998c, 2002, 2003; Bałaga et al. 2002; Szeroczyńska and Gąsiorowski 2002). I always keep in mind what David Frey said to hydrobiologists at the Third International Symposium on Cladocera (9-16 August 1993, Bergen, Norway): "To understand the conditions prevailing in today's lakes, we need to learn about their condition and development in the past, and for this we need paleolimnology." It was in Bergen that I presented, for the first time, data on subfossil Cladocera from laminated sediments of Lake Gościąż. The data triggered considerable discussion, which was continued in private by Symposium participants during a coffee break. As you can see in Fig. 1, Henri Dumont was an active discussant among the hydrobiologists. To this day, whenever I meet Professor Dumont at scientific conferences, we always find time for discussions, for which I am very grateful.

In the 1990s, I used Cladocera to the maximum extent possible as indicators of environmental changes through time. I observed clear boundaries with respect to composition and frequency of Cladocera species in sediment profiles, in both mountain and lowland lakes, especially across cold and warm periods. Regardless of the type and location of a lake, I always found a quantitative and qualitative change in Cladocera during the transition period between the Late Glacial and the Holocene (Szeroczyńska 1984, 2006; Szeroczyńska and Milecka 2007; Zawisza and Szeroczyńska 2007). I used this information for "biostratigraphic" purposes, mainly for determining the Late Glacial/Holocene boundary (Figs. 2, 3). The results formed the basis of a number of published papers on the importance of subfossil Cladocera for documenting climate change, as well as changes in trophic state conditions and water level in lakes (Szeroczyńska 1998d, 2002; Sarmaja-Korjonen et al. 2003; Gąsiorowski and Szeroczyńska 2004). With respect to the historical period, from the Mesolithic to

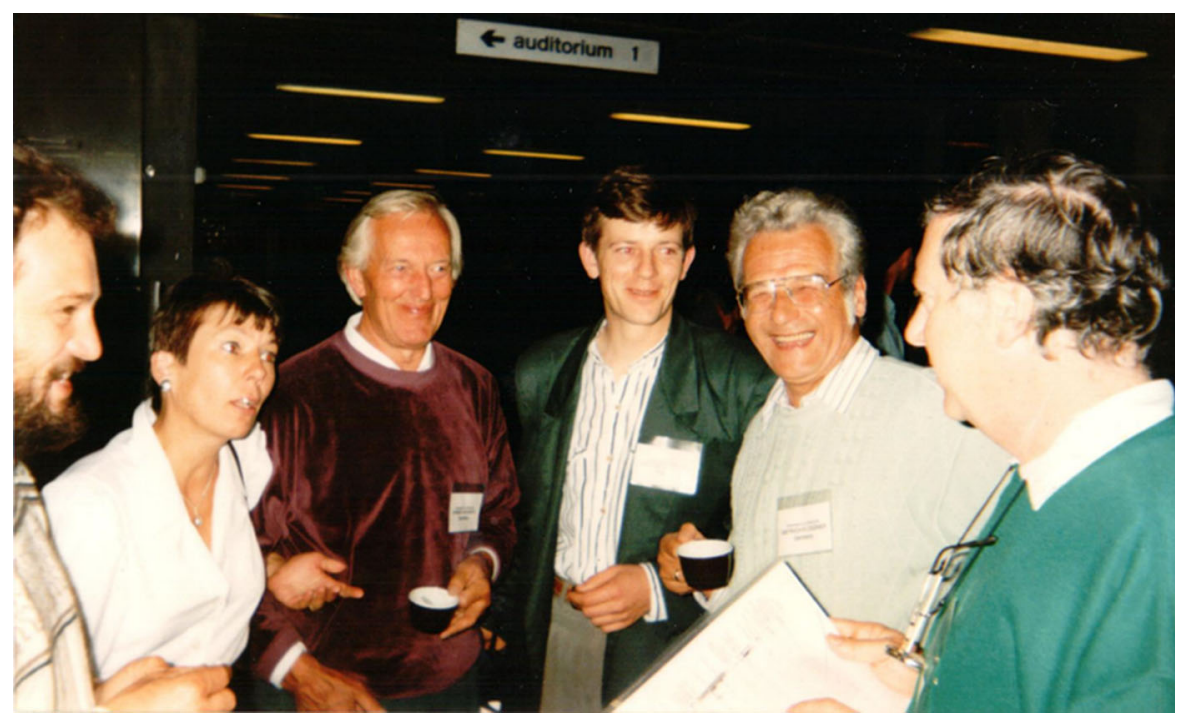

Fig. 1 Discussion about data of Gościąż Lake among (from the left to right) Anton Brancelj, Krystyna Szeroczyńska, Werner Hollwedel, Zdzisław Niewiadomski, Dietrich Flößner and
Henri J. Dumont — coffee break, Third International Symposium on Cladocera, Bergen, Norway, 9-16 August 1993 
(A)

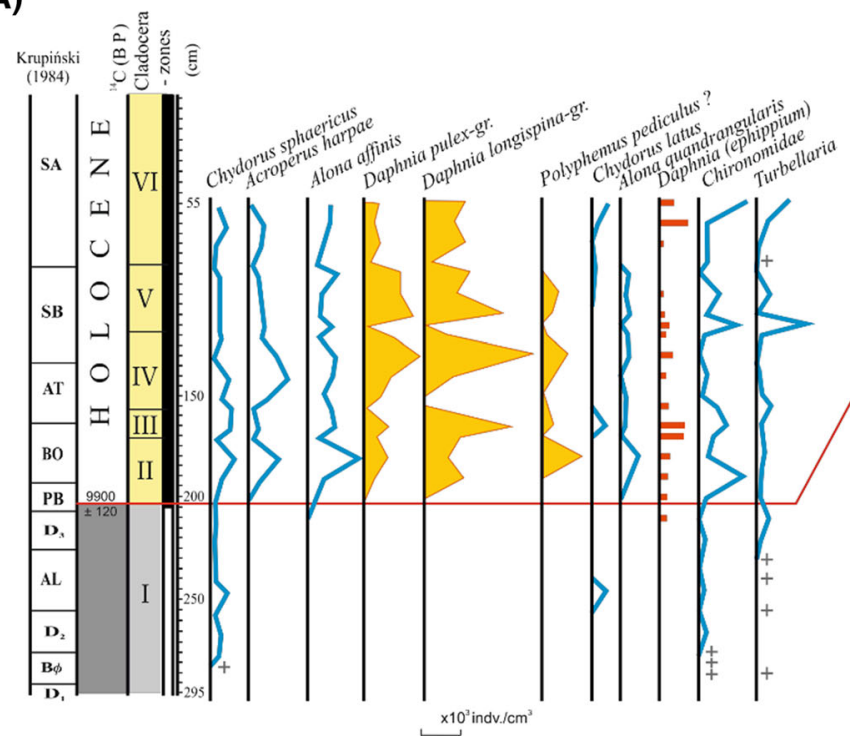

(B)

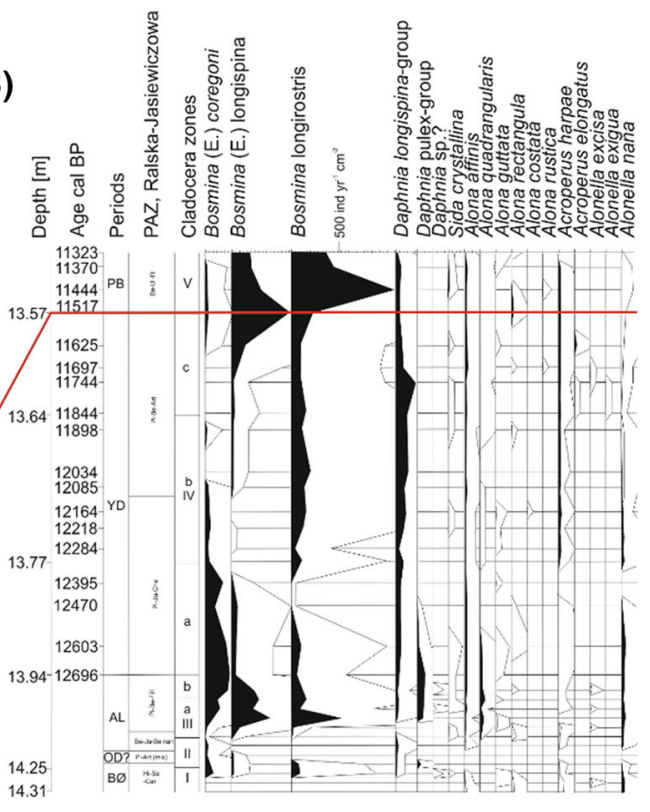

Fig. 2 Late Glacial to Holocene stratigraphy of species composition and frequency of individuals of Cladocera in the sediment of a Lake Przedni Staw (Tatra Mts.) and b Lake Gościąż (Central Poland). Modified from Szeroczyńska (1998c, d)

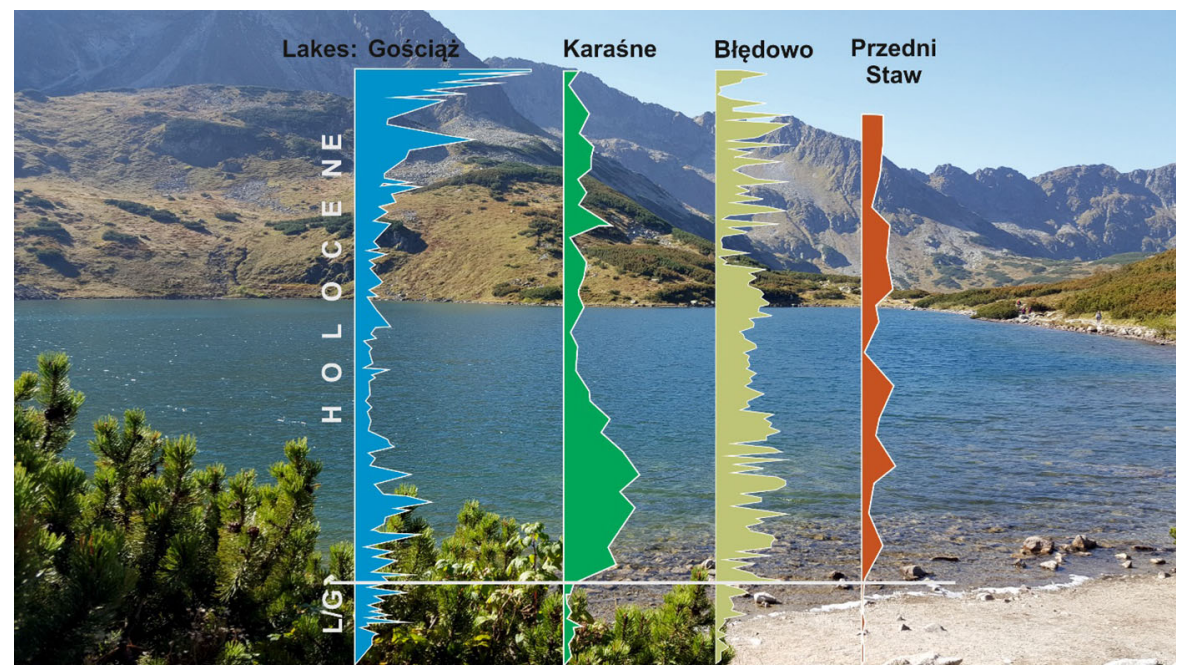

Fig. 3 Late Glacial (L/G) to Holocene stratigraphy of Cladocera remains in the sediments of lowland Lakes Gościąż, Karaśne and Błędowo, and mountain Lake Przedni Staw (photo

the present day, I demonstrated the impact of human economic activity, as well as the impact of climate, on the development of Cladocera and the trophic state of lakes (Milecka and Szeroczyńska 2005; Milecka et al. 2011). The research I conducted until 1998 became the basis for my postdoctoral thesis, i.e. habilitation (Szeroczyńska 1998a, b, c; Szeroczyńska and Polcyn
O. Augustyniuk, x-axis: Total Cladocera indv. $/ 1 \mathrm{~cm}^{3}$ fresh sediments) (Szeroczynska 1998d, 2003)

1998), and the achievement of an academic degree (Dr. DSc.) that allows me to supervise theses of $\mathrm{PhD}$ students. 


\section{Influence of international contacts}

The international collaborations I established in the 1990s were important to my academic career and had a great impact on my scientific work. Those collaborations yielded several co-authored publications that involved the analysis of subfossil Cladocera and reconstruction of climate change in time and space. International contacts and scholarships enabled me to conduct research on lacustrine deposits outside Poland. Cooperation with colleagues Roland Schmidt and Christian Kamenik, from the Research Institute for Limnology in Mondsee (Austria), proved very rewarding, and outcomes included the analysis of Cladocera remains from sediments of Lake Vrana (Cres, Croatia) and from northern Adriatic Valun Bay (Schmidt et al. 2000, 2001a, b). The above examples illustrate the importance of collaborations between experts. Other data, especially palynological information used to determine the human settlement phases, enabled interpretation of data on species composition and abundance of subfossil Cladocera. The plot of Cladocera frequency in deep Lake Vrana could not have been interpreted correctly without data on human settlement phases. The sudden appearance of planktonic Cladocera species in the late Holocene (ca. $2.8 \mathrm{ka} \mathrm{BP}$ ) was clearly a result of water-column nutrient enrichment, i.e. an anthropogenic effect. This applies particularly to the Roman and Medieval Period settlement phases, and was not, as the species composition might have indicated, a consequence of changes in water level (Fig. 4). Together with Roland Schmidt and Christian Kamenik, I was also able to analyse sediments from Alpine lakes (Austria), located relatively close to one another, but at different altitudes (Kamenik et al. 2007). The results showed a high correlation between Cladocera species composition and lake morphometry, but above all, with altitude, water temperature and solar irradiance (Fig. 5).

One of my most rewarding international collaborations has involved long-term cooperation with scientists from the University of Helsinki, in particular Kaarina Sarmaja-Korjonen and Atte Korhola (Sarmaja-Korjonen et al. 2003; Szeroczyńska et al. 2007). The number of European specialists using Cladocera remains to study changes in the natural environment has increased tremendously owing to a number of workshops on subfossil Cladocera (Bjerring et al.
2008; Köver et al. 2012). The first workshop was organised in 1999 in Helsinki by Atte Korhola. Since then, the annual workshops were organised in different European countries, with professional support from Kaarina Sarmaja-Korjonen and me, as well as other experts (Fig. 6). In 2018, the XV Subfossil Cladocera Workshop was held in Veszpren, Hungary and attended by 22 scientists. Each workshop brought together both junior and senior researchers, which promoted an exchange of knowledge and in-depth study of the identification of Cladocera remains. One rewarding outcome of my cooperation with Kaarina Sarmaja-Korjonen was the publication of the first professional key for identification of Cladocera remains (Szeroczyńska and Sarmaja-Korjonen 2007). The taxonomic key was created thanks to the enormous efforts and commitment of Kaarina, to whom I am extremely grateful. This publication has facilitated identification of Cladocera remains and contributed to greater use of Cladocera remains in paleoenvironmental research. I thank the many people who helped us during our work on the Atlas (Szeroczyńska and Sarmaja-Korjonen 2007). I cannot list everyone, but I would particularly like to acknowledge younger colleagues who supported us with technical assistance, as well as, among others, John Smol for encouraging the idea of a taxonomic identification key, Adam Jeziorski for nomenclature and language verification, and Jarosław Pająkowski for facilitating swift publication of the Atlas. Publication of a professional identification key facilitated the work of junior researchers and led to greater interest in the analysis of Cladocera remains, and thus to an increase in the number of specialists in Europe who incorporate cladoceran analysis into paleolimnological studies.

In Poland, and especially at the Institute of Geological Sciences PAS, the interest in paleolimnology continues to grow. My PhD students not only conduct basic analyses on Cladocera remains, but have developed a number of methodological modifications, and expanded application of Cladocera analysis for sediment studies across time and space. Monika Niska is an expert in the analysis of Eemian (ca. 130-115 ka) Cladocera remains from lacustrine sediments (Mirosław-Grabowska et al. 2018). Michał Gąsiorowski (Galbarczyk-Gąsiorowska et al. 2009), Jarosław Pająkowski (Kowalewski et al. 2001), Edyta Zawisza (Antipushina et al. 2012; Zawiska et al. 2013), 


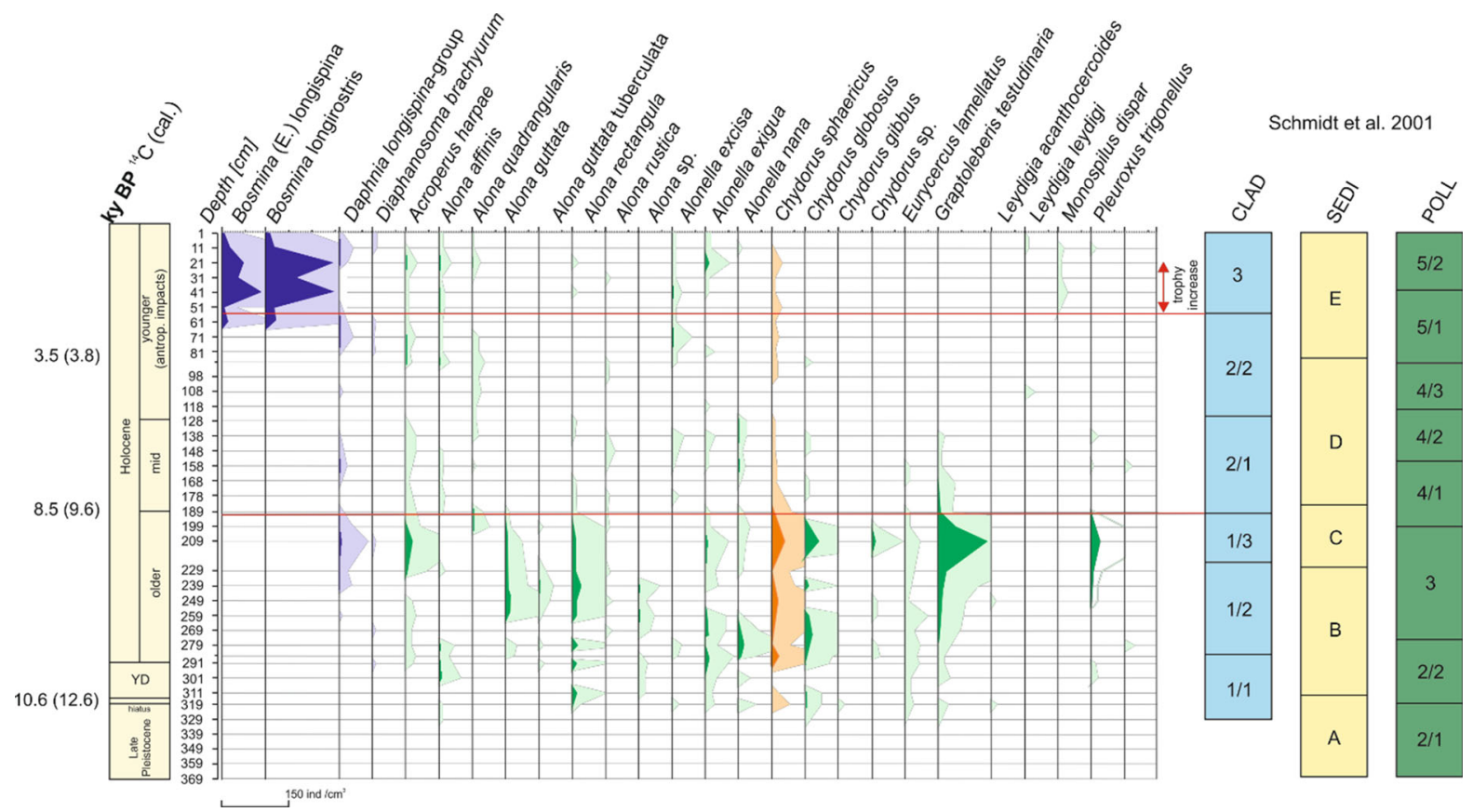

Fig. 4 Absolute frequency of Cladocera species in the sediment of Lake Vrana (Cres, Adriatic) in relation to sedimentological units (SEDI) and pollen zones (POLL). Littoral Cladocera species during Cladocera zone 1 (CLAD) indicate low lake level. From zone 2, the lake was probably deep and oligotrophic, with very low abundance of Cladocera. The

Magdalena Suchora (Fiłoc et al. 2017) and Manuela Milan (Milan et al. 2017) have analysed Cladocera remains to explore the genesis and ontogeny of water bodies, including oxbow lakes, peat bogs, and both shallow and deep lakes of different trophic status. In addition to Cladocera analysis, these researchers conducted chemical analyses and other biological analyses, to reconstruct past conditions. Each of them continues to carry out paleolimnological research at her or his home academic institution.

At the Institute of Geological Sciences of the Polish Academy of Sciences, where the research focus is mainly geology, there is a large group involved in paleolimnological studies. The group uses subfossil Cladocera analysis, combined with other methods, e.g. palynology (M. Obremska), diatoms (E. Sienkiewicz), stable isotopes (J. Mirosław-Grabowska), and ${ }^{210} \mathrm{~Pb} /{ }^{137} \mathrm{Cs}$ dating (M. Gąsiorowski) to reconstruct climate and ecological changes that have occurred in the remote and more recent past. species composition changed during zone 3 , and the assemblage was dominated by planktonic species (Bosminidae). The presence of Bosmina longirostris suggests an increase in nutrients and rising trophic state, which was probably associated with human impact. Modified from Schmidt et al. (2001a, b)

\section{Bilateral foreign projects}

Throughout my career I have developed new foreign contacts and this has led to a number of joint research projects, with the participation of other Institute of Geological Sciences employees. These projects involved research on sediments of lakes in both cold and warm areas. The objectives of the research were not limited to reconstruction of the evolution of the lakes, but also included documentation of past climate shifts and/or the effects of human activities. Together with Finnish scientists, we carried out a study on sediments from lakes in Lapland. Lakes Somaslampi and Kevo, among others, were studied as part of the LABIAT I and LABIAT II projects (Lapland Biosphere-Atmosphere Facility (LABIAT) Finland). Chemical and biological (diatoms, cladoceran) analysis, combined with sediment dating, enabled us to determine the past hydrology of lakes and climate changes that prevailed in the vicinity of the water bodies from the Late Glacial to present (Szeroczyńska et al. 2007; Szeroczyńska and Zawisza 2011a). 


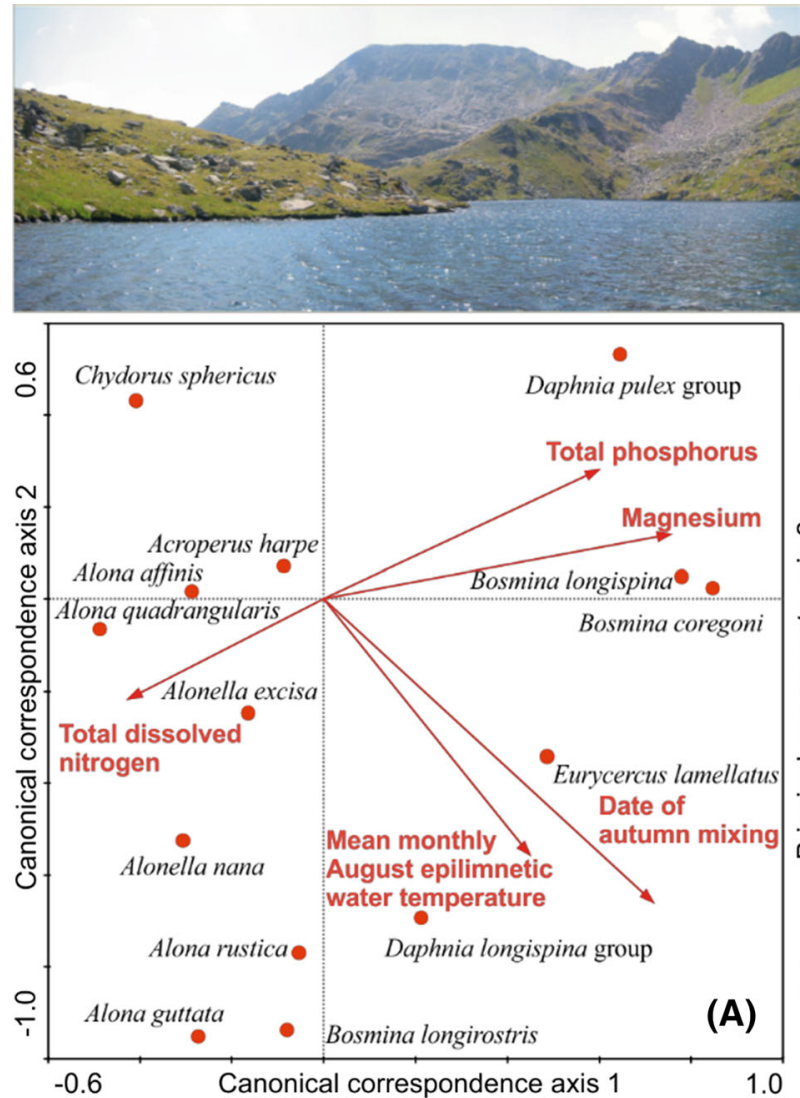

Fig. 5 Correlation of Cladocera assemblages with environmental variables, from surface sediments of 44 alpine lakes in the central Austrian Alps. Dataset included water chemistry, temperature, depth, spring and autumn mixing, and was analysed using numerical methods PCA and CCA. Lake Weissensee photo by Ch. Kamenik. a Canonical correspondence analysis from changes in the assemblages of 14 subfossil Cladocera from 36 lakes, related to five environmental variables. Variables were selected on the basis of significant

Another subject of my research was the sediment of Spitsbergen's (Norway) water bodies, a project undertaken in cooperation with Edyta Zawisza. The species composition of phytoplankton and zooplankton in these shallow lakes is much poorer than that in Lapland lakes, which indicates the influence of a more Arctic climate on Cladocera (Szeroczyńska and Zawisza 2011a; Zawisza and Szeroczyńska 2011). The effects of continental versus Atlantic climate were also demonstrated by results of research conducted on lakes in northern Poland (Szeroczyńska and Zawisza 2005, 2011a; Zawisza and Szeroczyńska 2007; Drzymulska et al. 2015). Subfossil Cladocera were also used to address the occurrence of cold events

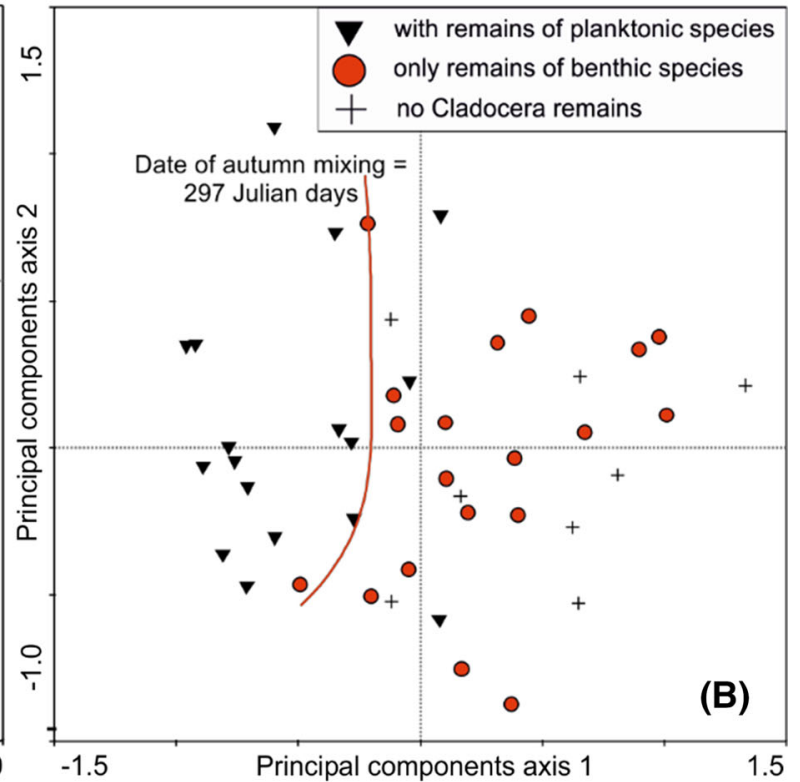

$(P<0.05)$ marginal effects. b Principal components analysisaxis 1 versus axis 2 , based on abiotic variables (axis 1 for climate, axis 2 for nutrients). Samples were grouped by lake: those lacking Cladocera remains ( 8 lakes), those with only benthic species (18), and those having benthic and planktonic species (19). The transition from lakes with planktonic taxa to lakes without remains of planktonic Cladocera is roughly related to the date of autumn mixing. Modified from Kamenik et al. (2007)

associated with the PDO, 8.2-ka, and the Little Ice Age (Szeroczyńska and Zawisza 2011b; Fiłoc et al. 2017; Zawisza et al. 2017). Lakes in warm, tropical areas were analysed in cooperation with Edyta Zawisza and Margarita Caballero (UNAM, Mexico) as part of joint research projects (Szeroczyńska and Zawisza 2015; Szeroczyńska et al. 2015; Zawisza et al. 2017; Hamerlik et al. 2018). Mexican Lakes Sol and Luna, located in the crater of the Nevado de Toluca volcano, and several cenotes (sinkhole lakes), were examined in pilot studies. Phytoplankton and zooplankton responses to Little Ice Age climate were recorded in sediments of these lakes, and the last eruption of Nevado de Toluca was dated with better accuracy. 


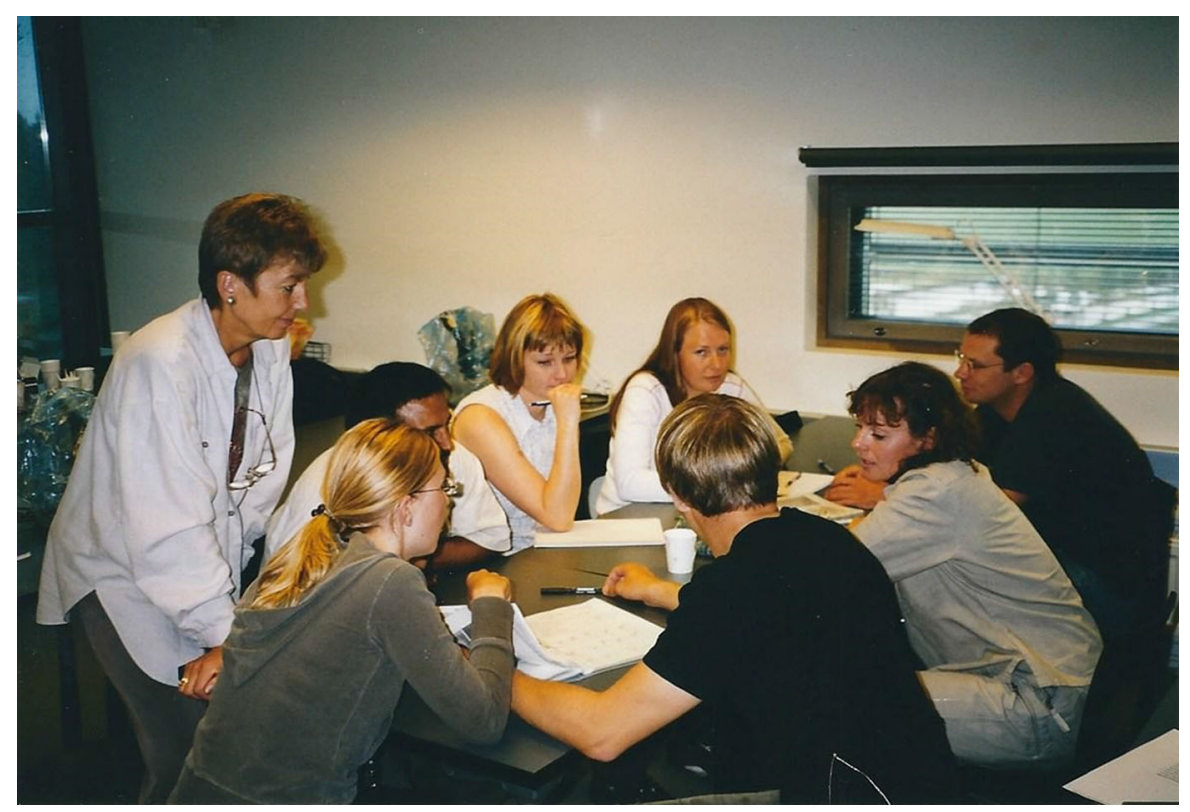

Fig. 6 Krystyna Szeroczyńska and workshop participants examining Cladocera remains during Vth International Subfossil Cladocera Workshop, 22-24 August 2003, Espoo, Finland

Research on tropical lakes continued in cooperation with Antje Schwalb (Technische Universität, Braunschweig, Germany). Sediment samples from the PISDP (Lake Peten-Itza Scientific Drilling Project) were used to assess qualitative and quantitative species composition of Cladocera in sediments of Lake Peten-Itza (Guatemala). These sediments recorded prevailing conditions during the late Quaternary. For the first time, I was able to study invertebrate species composition during cold periods, the so-called Heinrich Events (Cohuo et al. 2018). Associated with the doctoral theses of Sergio Cohuo and Laura Macario-Gonzalez, carried out under the direction of A. Schwalb, I was provided with sediment samples for subfossil Cladocera analysis, and collaborated on analyses with E. Zawisza and M. Wojewódka, on research on lakes in El Salvador, Guatemala and Honduras. The effects of climate change (Little Ice Age), as well as intense human activities, were studied using sediment cores from these lakes (Wojewódka et al. 2018).

Human impacts on lakes have always aroused my interest. Since the 1980s, both subfossil Cladocera and analysis of the eutrophication process have been my passions. I've explored why some lakes in an area become eutrophic and are transformed into peat bogs, whereas others, even of similar morphometry, turn into dystrophic water bodies (Szeroczyńska and Gąsiorowski 2002; Szeroczyńska 2003; Kowalewski et al. 2013; Drzymulska et al. 2015; Zawisza et al. 2019). While studying the sediments and inferring past changes that occurred in the lake environment over the centuries, I observed large changes in the Cladocera fauna. The diversity of the study lakes, from oligotrophic to hypereutrophic to dystrophic, shallow and deep, enabled me to observe the adaptability of the Cladocera fauna, as well as their ecological tolerances (Kowalewski et al. 2013; Sapelko et al. 2013; Szeroczyńska 2016). Analysis of cladoceran remains revealed changes in community structure and morphology within a species, which made it possible to observe the adaptations of organisms to changing environmental conditions in lakes, especially to extreme conditions like high turbidity, lake acidification, and algal blooms. Adaptations are frequently observed in individuals of the family Bosminidae, which produce extreme morphs during unfavourable seasons (Gąsiorowski and Szeroczyńska 2004; Błędzki et al. 2013; Błędzki and Szeroczyńska 2015). The question remains as to why such Bosmina forms appear only in some lakes. I found extreme morphs mainly in relatively deep lakes. In Poland, I found them in organic sediments of Lake Ostrowite (40 $\mathrm{m}$ deep), but only in some layers, i.e. during 
specific periods of sedimentation (Gąsiorowski and Szeroczyńska 2004). I did not, however, find them in nearby Charzykowskie Lake ( $31 \mathrm{~m}$ deep) (Szeroczyńska and Zawisza 2011b). Therefore, the question arises as to what accounts for such differences in the development of the Cladocera fauna in lakes located close to one another and characterised by similar morphometry. Achim Brauer and Nadine Dräger (GeoForschungsZentrum, Potsdam, Germany) provided me with well dated sediments (partially laminated) from Lake Tiefer See (Germany), in which I found extreme morphs that enabled me to investigate the question of their occurrence more thoroughly, in time and space (Dräger et al. 2016; Szeroczyńska 2016). In combination with the results of other analyses carried out on the same sediment layers, we concluded that the occurrence of such morphs is likely controlled by multiple factors, e.g. water turbidity and/ or fish predation pressure. That, however, is only a hypothesis, which requires further analysis.

The first occurrence of Bosmina thersites in sediments of Baltic lakes, deposited ca. 800 years ago, is also puzzling (Błędzki et al. 2013; Błędzki and Szeroczyńska 2015). I have never found this species in older sediments. Perhaps the species arrived recently in the Baltic area, along with human migrants. Or possibly, it appeared in response to specific conditions related to the influence of coastal climate, which could have caused the transformation of one of the species in the family Bosminidae.

\section{The future}

There is still plenty to explore in the field of subfossil Cladocera analysis. My young colleagues, i.e. the many students and others who have participated in workshops on subfossil Cladocera, and who are passionately involved in the analysis of Cladocera remains, will address the challenges (Fig. 7). In the future, statistical analyses and models will be applied and all variables and physico-chemical factors that influence Cladocera will be taken into account. This will make it possible to draw more realistic inferences about the changes that occurred in the past, to better understand current conditions, and to predict future environmental conditions in lakes. Many investigators have applied modelling successfully, enabling them to

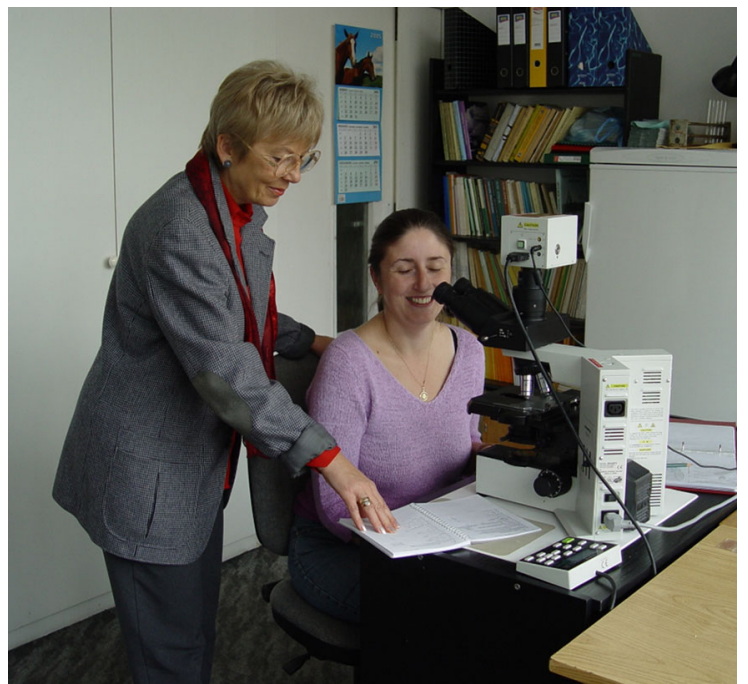

Fig. 7 Krystyna Szeroczyńska and Edyta Zawisza working on cladoceran remains at the Institute of Geological Sciences PAS

better understand changes caused by natural and anthropogenic factors (Luoto and Nevalainen 2018).

I have always been intrigued by how long Cladocera remains are preserved in lake sediments. Research suggested that Cladocera remains could be preserved in sediments as old as $\sim 300,000$ years. Recent studies, however, indicate that this age was far too conservative. Indeed, Cladocera remains were recently found in sediments deposited in the Neogene, ca. 10,000,000 years ago (Zawisza et al. 2018). Therefore, the use of these bioindicators in "paleo" studies will no doubt increase in the future. In this current time of global climate and ecological changes, any bioindicator that can be used to infer past climate and environmental change must be given serious consideration. Subfossil Cladocera certainly qualify.

After more than 40 years, my adventure with subfossil Cladocera is coming to an end. Nevertheless, I know that research on this fascinating invertebrate group will continue to flourish under the direction my many young colleagues, who have been "hooked by the Cladocera-paleolimnology bug." It brings me great satisfaction knowing that the research that so captivated me will be continued by my studentsscientists who not only use the knowledge they have been taught, but also broaden the scope of research. At present, there are about 15 scientists in Poland (the largest group in Europe), who are experts in subfossil Cladocera analysis. I support them all and hope that 
one day they will also recognize their scientific work has been a great life adventure.

Acknowledgements I thank all my Polish and foreign colleagues with whom I have had the pleasure of working during different stages of my career. I am very grateful to them for their knowledge, understanding and friendship. I acknowledge my foreign colleagues for their support during my stays at their Institutes and for many fruitful discussions. I am very grateful to Professors E. Jeppesen (National Environmental Research Institute, Silkeborg, Denmark), R. Battarbee (University College, London, Great Britain), N.N. Smirnov and A.A. Kotov (A.N. Severtsov Institute of Ecology and Evolution, Moscow, Russia), E. Vicente and M.R. Miracle (University of Valentia, Spain). I thank A. Korhola (University of Helsinki) for organising the expedition and unforgettable moments during sampling in Lapland lakes. I thank M. Caballero (UNAM, Mexico), B. Xue (Nanjing Institute of Geography and Limnology, Nanjing, China), A. Schwalb (Technische Universität, Braunschweig, Germany) and Philipp Hoelzmann (Freie Universität, Berlin, Germany) for cooperation and joint research. I am grateful to all my Polish colleagues and friends, students and technical assistants, who have always been ready to help. I am most grateful to Professor T. Madeyska, who supported me with advice and help throughout my academic career. I am also indebted to the Directors of my Institute, Professors M. Lewandowski and E. Słaby, for fruitful cooperation during my time as Head of the Research Centre in Warsaw. I thank Professors W. Alexandrowicz, L. Starkel, L. Marks, J. Mirosław-Grabowska and E. Zawisza for professional collaboration during work carried out by the Committee for Quaternary Research PAS and INQUA. Lastly, I thank the Polish grant agency NCN (National Science Centre) for funding the scientific Projects (2012/05/B/ ST10/00469 and 2014/13/B/ST10/02534) that enabled productive international collaborations. In addition, a great thank you to Mark Brenner for carefully reviewing the manuscript.

Open Access This article is distributed under the terms of the Creative Commons Attribution 4.0 International License (http:// creativecommons.org/licenses/by/4.0/), which permits unrestricted use, distribution, and reproduction in any medium, provided you give appropriate credit to the original author(s) and the source, provide a link to the Creative Commons license, and indicate if changes were made.

\section{References}

Antipushina Z, Szeroczyńska K, Zawisza E (2012) Algal and invertebrate microfossil assemblages from lake sediments in the reconstruction of past community dynamics-preliminary information. Stud Quat 29:53-58

Bałaga K, Szeroczyńska K, Taras H, Magierski J (2002) Natural and anthropogenic conditioning of the development of Lake Perespilno (Lublin Polesie) in the Holocene. Limnol Rev 2:15-27
Bińka K, Madeyska T, Marciniak B, Szeroczyńska K, Więckowski K (1988) Błędowo Lake (Central Poland), history of vegetation and lake development during the last 12 00 years. Bull Pol Acad Sci Earth Scci 36:147-159

Bińka K, Cieśla A, Łącka B, Madeyska T, Marciniak B, Szeroczyńska K, Więckowski K (1991) The development of Błędowo Lake (Central Poland) - a palaeoecological study. Stud Geol Pol 100:1-86

Bjerring R, Nykanen M, Sarmaja-Korjonen K, Sinev A, Jensen K, Nevalainen L, Szeroczyńska K, Zawisza E (2008) Description of the subfossil head shield of Alona protzi hartwig 1900 (Anomopoda, Chydoridae) and the environmental characteristics of its finding sites. Stud Quat 25:47-53

Błędzki LA, Szeroczyńska K (2015) Palaeolimnological evidence of Bosmina morphotypes appearance in the late Holocene. Holocene 25:557-562

Błędzki LA, Szeroczyńska K, Puusepp E (2013) The late Holocene appearance of European Bosmina (Eubosmina) thersites (Crustacea, Cladocera) in lakes surrounding the Baltic Sea. Hydrobiologia 715:77-86

Cohuo S, Macario González L, Pérez L, Sylvestre F, Paillès Ch, Curtis J, Kutterolf S, Wojewódka M, Zawisza E, Szeroczyńska K, Schwalb A (2018) Climate ultrastructure and aquatic community response to Heinrich Stadials (HS5aHS1) in the continental northern Neotropics. Quat Sci Rev 197:75-91

Czeczuga B, Kosacka W (1977) Ecological changes in Wigry lake in the post-Glacial Period Part II. Investigation of the cladoceran stratigraphy. Pol Arch Hydrobiol 24:259-277

Dräger N, Theuerkauf M, Szeroczyńska K, Wulf S, Tjallingii R, Plessen B, Kienel U, Brauer A (2016) Varve microfacies and varve preservation record of climate change and human impact for the last 6000 years at Lake Tiefer See (NE Germany). Holocene 27:450-464

Drzymulska D, Fiłoc M, Kupryjanowicz M, Szeroczyńska K, Zieliński P (2015) Postglacial shifts in lake trophic status based on a multiproxy study of humic lake. Holocene 25:495-507

Fiłoc M, Kupryjanowicz M, Szeroczyńska M, Suchora M, Rzodkiewicz (2017) Environmental changes related to the 8.2-ka event and other climate fluctuations during the middle Holocene: evidence from two dystrophic lakes in NE Poland. Holocene 27:1550-1566

Galbarczyk-Gąsiorowska L, Gąsiorowski M, Szeroczyńska K (2009) Reconstruction of human influence on two small oxbow lakes. Hydrobiologia 631:173-183

Gąsiorowski M, Szeroczyńska K (2004) Abrupt changes in species structure of genus Bosmina during the history of the Ostrowite Lake (northern Poland). Hydrobiologia 526:137-144

Goslar T, Kuc T, Pazdur M, Ralska-Jasiewiczowa M, Różański M, Szeroczyńska K, Walanus A (1991) Possibilities of reconstruction of radiocarbon level changes during the Late Glacial by laminated sequence of the Gościąż Lake. Radiocarbon 34:826-838

Goslar T, Kuc T, Ralska-Jasiewiczowa M, Arnold M, Board E, van Geel B, Pazdur M, Różański K, Szeroczyńska K, Wicik B, Więckowski K, Walanus A (1993) High resolution lacustrine record at the Late-Glacial/Holocenetransgression in Central Europe. Quat Sci Rev 12:287-294 
Goslar T, Ralska-Jasiewiczowa M, van Geel B, Łącka B, Szeroczyńska K (1997) Anthropogenic changes in the composition of Lake Gościąż (central Poland) sediments, during the last 300 years. Würzbg Geogr Manuskr 41:81-82

Goslar T, Ralska-Jasiewiczowa M, van Geel B, Łącka B, Szeroczyńska K, Chróst L, Walanus A (1999) Anthropogenic changes in the sediment composition of Lake Gościąż (central Poland), during the last 330 yrs. J Paleolimnol 22:171-185

Hamerlik L, Wojewódka M, Zawisza E, Cohuo Duran S, Macario-Gonalez L, Perez L, Szeroczyńska K (2018) Subfossil Chironomidae (Diptera) in surface sediments of the sinkholes (cenotes) of the Yucatan Peninsula: diversity and distribution. J Limnol 77:213-219

Kamenik C, Szeroczyńska K, Schmidt R (2007) Relationships among recent Alpine Cladocera remains and their environment: implications for climate-change studies. Hydrobiologia 594:33-46

Kopczyńska-Lamparska K, Cieśla A, Marciniak B, Skompski S, Szeroczyńska K (1983) Stratigraphie der spätglazialen Sedimente und Eisabbau in der Umgebung von Niechorze/ NW-Pomorze, VR Polen/. In: Kliewe H, Galon R, Jäger $\mathrm{KD}$, Niewiarowski W (eds) Das Jungquartär und seine Nutzung. VEB Hermann Haack, Gotha, pp 59-65

Korhola A, Rautio M (2001) Cladocera and other Branchiopod crustaceans. In: Smol JP, Birks JB, Last WM (eds) Tracking environmental change using lake cediments, zoological indicators. Kluwer Academic Publishers, Dordrecht, pp 5-41

Köver C, Korponai J, Katalinic A, Bereczki C (2012) Distribution of Cladocera communities across a climate gradient in shallow lakes from Croatia to Hungary. Stud Quat 28:45-52

Kowalewski G, Lamentowicz M, Pająkowski J (2001) Lake Miedzno shoreline changes and lake Piaseczno sediments in Wdecki Landscape Park area. Limnol Rev 1:173-181

Kowalewski G, Kornijow R, McGowan S, Wołoszczyk M, Suchora M, Bałaga K, Kaczorowska A, Gąsiorowski M, Szeroczyńska K, Wasiłowska A (2013) Persistence of protected, vulnerable macrophyte species in a small, shallow eutrophic lake (eastern Poland) over the past two centuries: implications for lake management and conservation. Aquat Bot 106:1-13

Luoto TP, Nevalainen L (2018) Temperature-precipitation relationship of the Common Era in northern Europe. Theor Appl Climatol 132:933-938

Mikulski J (1978) Man impact upon Gopło Lake as reflected in cladoceran-community remnants in sediments. Pol Arch Hydrobiol 25:291-295

Milan M, Bigler Ch, Tolotti M, Szeroczyńska K (2017) Effects of long term nutrient and climate variability on subfossil Cladocera in a deep, subalpine lake (Lake Garda, northern Italy). J Paleolimnol 58:335-351

Milecka K, Szeroczyńska K (2005) Changes in macrophytic flora and planktonic organisms in Lake Ostrowite, Poland, as a response to climatic and trophic fluctuations. Holocene 15:77-87

Milecka K, Kowalewski G, Szeroczyńska K (2011) Climaterelated changes during the Late Glacial and Early Holocene in northern Poland, as derived from the sediments of Lake Sierzysk. Hydrobiologia 676:187-202

Mirosław-Grabowska J, Niska M, Roman M (2018) Long (MIS $5 e-3)$ environmental history of a paleolake in central Poland recorded in the succession from Kubłowo. Quat Int 467:26-42

Pawlikowski M, Ralska-Jasiewiczowa M, Schönborn W, Stupnicka E, Szeroczyńska K (1982) Woryty near Gietrzwałd, Olsztyn lake district, NE Poland-vegetational history and lake development during the last 12000 years. Acta Palaeobot 22:85-116

Ralska-Jasiewiczowa M, van Geel B, Goslar T, Pelisiak A, Rybicka M, Szeroczyńska (1997) Lake Gościąż, central Poland-human impact on surrounding vegetation and lake history from Mesolithic till recent times. Würzbg Geogr Manuskr 41:163-164

Ralska-Jasiewiczowa M, Goslar T, Madeyska T, Starkel L (eds) (1998) Lake Gościąż Central Poland a monographic study. W Szafer Institute of Botany PAS, Kraków

Sapelko TV, Smirnov NN, Szeroczyńska K, Khasanov BF, Bayanov NG, Kuznetsov DD, Antipushina ZA (2013) History of Glubokoe Lake (Moscow Oblast) Revealed by Analysis of Bottom Deposits. Dokl Earth Sci Geogr 450:571-574

Sarmaja-Korjonen K, Szeroczyńska K, Gąsiorowski M (2003) Subfossil chydorid taxa and assemblages in Holocene lake sediments from Poland and Finland. Stud Quat 20:25-34

Schmidt R, Muller J, Drescher-Szneider R, Krisai R, Szeroczyńska K, Baric A (2000) Changes in lake level and trophy at Lake Vrana, a large karstic lake on the Island of Cres (Croatia), with respect to palaeoclimate and anthropogenic impacts during the last approx. 16,000 years. J Limnol 59:113-130

Schmidt R, Muller J, Drescher-Schneider R, Szeroczyńska K, Baric A, Krisai R (2001a) Changes in Holocene lake level and production in a large northern Adriatic karstic lake (Lake Vrana, Cres, Croatia). Terra Nostra 2:53-56

Schmidt R, Pugliese N, Muller J, Szeroczyńska K, Bogner D, Melis R, Kamenik C, Baric A, Danielopol DL (2001b) Palaeoclimate, vegetation and coastal lake development, from upper pleniglacial until early Holocene, in the northern Adriatic Valun Bay (Isle of Cres, Croatia). Il Quat 14:61-78

Smol JP (2012) Lakes and climate change: a paleoecological perspective. In: Freedman W (ed) Handbook of global environmental pollution. Springer, Dordrecht

Szeroczyńska K (1984) Analiza Cladocera w osadach niektórych jezior tatrzańskich (Results of examination of Cladocera remnants in lacustrine sediments of Dolina Pięciu Stawów Polskich). Prace i Stud Geogr 5:92-102

Szeroczyńska K (1985) Cladocera jako wskaźnik ekologiczny w późnoczwartorzędowych osadach jeziornych Polski Północnej. (Cladocera as ecological indicator in late quaternary lacustrine sediments, Northern Poland). Acta Palaeontol Pol 30:3-69

Szeroczyńska K (1991) Impact of prehistoric settlements on the Cladocera in the sediments of lakes Suszek, Błędowo, and Skrzetuszewskie. Hydrobiologia 225:105-115

Szeroczyńska K (1998a) Wioślarki (Cladocera, Crustacea) jako źródło informacji w badaniach osadów jeziornych. 
(Cladocera (Crustacea) as information source in studies of lake sediments). Studia Geol Pol 112:9-28

Szeroczyńska K (1998b) Holoceńska historia jezior Lednickiego Parku Krajobrazowego na podstawie kopalnych wioślarek. (The Holocene history of lakes Landscape Park based on fossil Cladocera). Stud Geol Pol 112:29-103

Szeroczyńska K (1998c) Anthropogenic transformation of nine lakes in Central Poland from Mesolithic to modern times in the light of Cladocera analysis. Stud Geol Pol 112:123-165

Szeroczyńska K (1998d) Palaeolimnological investigations in Poland based on Cladocera (Crustacea). Palaeogeogr Palaeoclimatol Palaeoecol 140:335-345

Szeroczyńska K (2002) Human impact on lakes recorded in the remains of Cladocera (Crustacea). Quat Int 95-96:165-174

Szeroczyńska K (2003) Cladoceran succession in lakes and peat bogs of Łęczna-Włodawa Lake District. Limnol Rev $3: 235-242$

Szeroczyńska K (2006) The significance of subfossil Cladocera in stratigraphy of Late Glacial and Holocene. Stud Quat 23:37-45

Szeroczyńska K (2016) Long term subfossil Cladocera recorded from the partly varved sediment of Lake Tiefer See (NE Germany). Adv Oceanogr Limnol (AiOL) 7:184-196

Szeroczyńska K, Gąsiorowski M (2002) Palaeohydrological aspect of transformation of lakes into peat bogs during Middle Holocene on the basis of Cladocera analysis in the northern Poland. Stud Quat 19:55-60

Szeroczyńska K, Milecka K (2007) Lobelia lakes-history recorded in plant and faunal (Cladocera) remains. Quartern Int 167-168:409

Szeroczyńska K, Polcyn I (1998) Cladocera w osadach pelagicznych Jeziora Biskupińskiego (Cladocera in pelagic sediments of the Biskupińskie Lake-Central Poland). Stud Geol Pol 112:105-122

Szeroczyńska K, Sarmaja-Korjonen K (2007) Atlas of subfossil Cladocera from Central and Northern Europe. Friends of the Lower Vistula Society, Poland

Szeroczyńska K, Zawisza E (2005) Daphnia remains from the sediments of Lake Somaslampi (NW Finnish Lapland) and Lake Wigry (NE Poland). Stud Quat 22:55-57

Szeroczyńska K, Zawisza E (2011a) Subfossil faunal and floral remains (Cladocera, Pediastrum) in lakes in two northern Lobelia lakes in Finland. Knowl Manag Aquat Ecosyst 402(09):1-15

Szeroczyńska K, Zawisza E (2011b) Records of the 8200 cal BP cold event reflected in the composition of subfossil Cladocera in the sediments of three lakes in Poland. Quatern Int 233:185-193

Szeroczyńska K, Zawisza E (2015) Cenotes-lakes of the Yucatan Peninsula (Mexico). Stud Quat 32:53-57
Szeroczyńska K, Tatur A, Weckstrom J, Gąsiorowski M, Noryśkiewicz A, Sienkiewicz E (2007) Holocene environmental history in northwest Finnish Lapland reflected in the multi-proxy record of small subarctic lake. J Paleolimnol 38:25-47

Szeroczyńska K, Zawisza E, Wojewódka M (2015) Initial time of two high altitude crater lakes (Nevado de Toluca, Central Mexico) recorded in subfossil Cladocera. Stud Quat 32:109-116

Wojewódka M, Hamerlik L, Krahn K, Zawisza E, Cohuo Duran S, Macario-Gonzalez L, Hoelzmann P, Rose NL, Yang H, Charqueño-Celis F, Schwalb A, Pérez L (2018) A multiproxy survey of recent environmental changes from the sediments of lake Apastapeque (El Salvador, Central America), 17-21 June 2018, IPA-IAL 2018 Unravelling the Past and the Future of Lakes, abstract book, pp 220

Zawiska I, Zawisza E, Woszczyk M, Szeroczyńska K, Spychalski W, Correa-Metrio A (2013) Cladocera and geochemical evidence from sediment cores show trophic changes in Polish dystrophic lakes. Hydrobiologia 715:181-193

Zawisza E, Szeroczyńska K (2007) The development history of Wigry Lake as shown by subfossil Cladocera. Geochronometria 27:67-74

Zawisza E, Szeroczyńska K (2011) Cladocera species composition in lakes in the area of the Horsund Fjord (Southern Spitsbergen)—preliminary results. Knowl Manag Aquat Ecosyst 402:04

Zawisza E, Cuna E, Caballero M, Ruiz-Fernandez AC, Szeroczyńska K, Wołoszczyk M, Zawiska I (2017) Environmental changes during the last millennium recorded in subfossil Cladocera, diatoms and sediment geochemistry from Lake El Sol (Central Mexico). Geol Q 61:81-90

Zawisza E, Pociecha A, Worobiec E, Szeroczyńska K, Worobiec G (2018) The oldest chitinous fossil remains of Cladocera from Miocene (12-8 million years ago) oxbow lake (Central Poland). In: IPA-IAL 2018 unravelling the past and the future of lakes, 17-21 June 2018, abstract book, pp 355

Zawisza E, Zawiska I, Szeroczyńska K, Correa-Metrio A, Mirosław-Grabowska J, Obremska M, Rzodkiewicz M, Słowiński M, Wołoszczyk M (2019) Dystrophication of Lake Suchar IV (NE Poland): an alternative way of lake development. Limnetica 38:391-416

Publisher's Note Springer Nature remains neutral with regard to jurisdictional claims in published maps and institutional affiliations. 